\title{
Geochemical Characterization of Base Metals in Stream Water and Sediments in the Caddo Lake Watershed, Cass, Harrison and Marion Counties, Texas
}

\author{
Melinda S. Faulkner*, Melanie L. Ertons, Joseph W. Watkins \\ Department of Geology, Stephen F. Austin State University, Nacogdoches, TX, USA \\ Email: *mgshaw@sfasu.edu
}

How to cite this paper: Faulkner, M. S., Ertons, M. L., \& Watkins, J. W. (2020). Geochemical Characterization of Base Metals in Stream Water and Sediments in the Caddo Lake Watershed, Cass, Harrison and Marion Counties, Texas. Journal of Geoscience and Environment Protection, 8, 1-23. https://doi.org/10.4236/gep.2020.89001

Received: July 31,2020

Accepted: September 5, 2020

Published: September 8, 2020

Copyright $\odot 2020$ by author(s) and Scientific Research Publishing Inc. This work is licensed under the Creative Commons Attribution International License (CC BY 4.0).

http://creativecommons.org/licenses/by/4.0/

\begin{abstract}
The Caddo Lake watershed is located in northeastern Texas and encompasses much of Cass, Harrison, and Marion counties. The watershed is drained by major streams and tributaries flowing in an easterly direction over Eocene-aged rocks and sediments of the Wilcox and Claiborne groups, and empty into the western arm of Caddo Lake. Since 1995, Caddo Lake and some of its tributaries have been included on the State of Texas Clean Water Act 303(d) list by the Texas Commission on Environmental Quality (TCEQ) for impairment due to mercury content in edible tissue, depressed dissolved oxygen, base metal concentrations, and low $\mathrm{pH}$ values. The purpose of this multi-year study was to characterize base metal concentrations in stream water and sediments in the Caddo Lake watershed, and document the potential watershed transport and contribution to the impairment of Caddo Lake. Recent water (n $=58)$ and sediment $(\mathrm{n}=116)$ sampling at 29 sites revealed copper, lead, and zinc concentrations within normal limits and below EPA actionable standards. Mercury concentrations were elevated at 21 of the 29 sampling sites, which could lead to methylation and bioavailability to organisms at all trophic level.
\end{abstract}

\section{Keywords}

Caddo Lake, Mercury, Base Metals, Geochemistry, Metal Transport

\section{Introduction}

Caddo Lake is a 25,400 -acre $(10,300$ ha) lake and associated wetland on the border between Texas and Louisiana. The lake and watershed covers approximately 
$164 \mathrm{~km}^{2}$ and encompasses much of Cass, Harrison and southern Marion counties in eastern Texas and western Caddo Parish in Louisiana. Caddo Lake drains an area of approximately $4247 \mathrm{~km}^{2}$ and has a storage capacity of $0.216 \mathrm{~km}^{3}$, with major tributaries including Big Cypress, Little Cypress, and Black Cypress bayous (Winemiller et al., 2005) accounting for approximately $70 \%$ of the total drainage area of the watershed (Figure 1).

In the early 20th century, Caddo Lake was the initial site for the establishment of overwater oil platforms, the precursor to platform drilling around the world. By 1914, the US Army Corps of Engineers had established a water navigation improvement plan to dredge the channels in the watershed to allow boats upriver and constructed an earthen dam to raise the water level in the lake (Winemiller et al., 2005). In 1971, 8000 acres of Caddo Lake and the watershed were designated as a Wetlands of International Importance by the Ramsar Convention; currently Caddo Lake is one of only 29 sites in the United States serving as an internationally protected wetland and includes one of the largest flooded cypress forests in the United States (Figure 2).

Historically, local and regional industries have affected metal concentrations in the Caddo Lake watershed. The oil industry active in the early 1900s left the area for richer fields in East and West Texas, with little to no remediation of well sites. In 1942, the Longhorn Army Ammunition Plant near Karnack, Texas produced trinitrotoluene (TNT) for World War II efforts and is currently designated as a superfund site (USFW, 2012). More recently, surface mining of lignite bearing units in the Wilcox Group and combustion of lignite to produce electrical energy has influenced many of the waterbodies in East Texas, and has been cited as one of the largest remaining anthropogenic sources of metals released to the atmosphere (EPA, 2015).

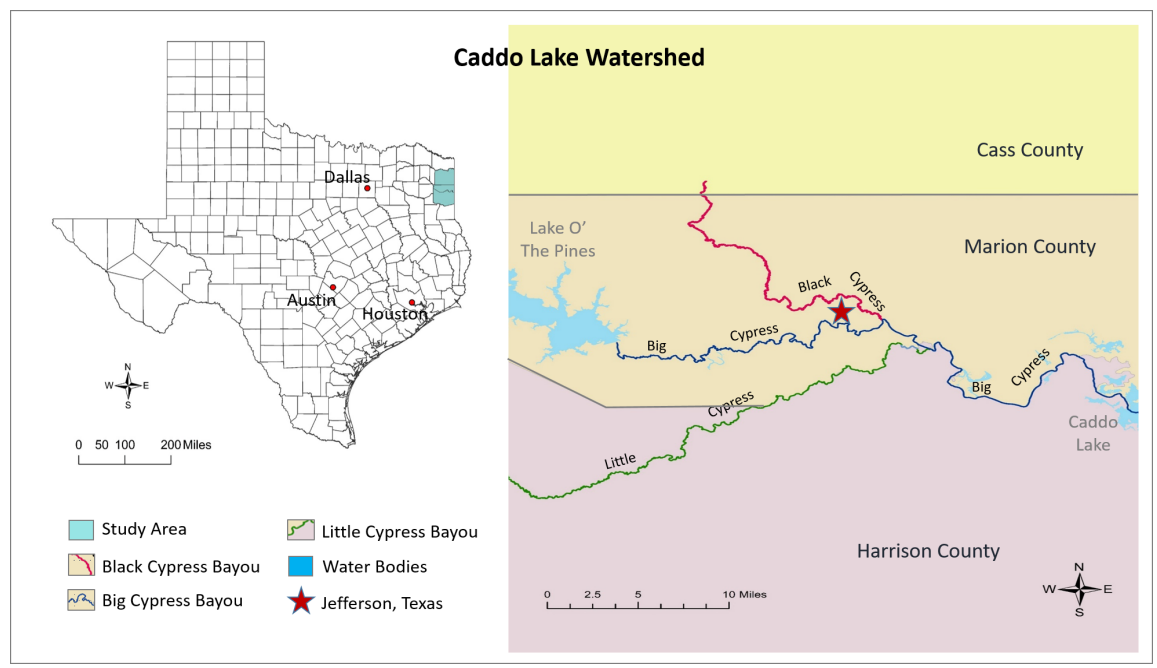

Figure 1. The Caddo Lake watershed is located in northeastern Texas and encompasses parts of Harrison, Marion and Cass counties. Black Cypress, Big Cypress, and Little Cypress bayous contribute over $70 \%$ of the flow into Caddo Lake, one of the largest flooded cypress ecosystems in the United States. 

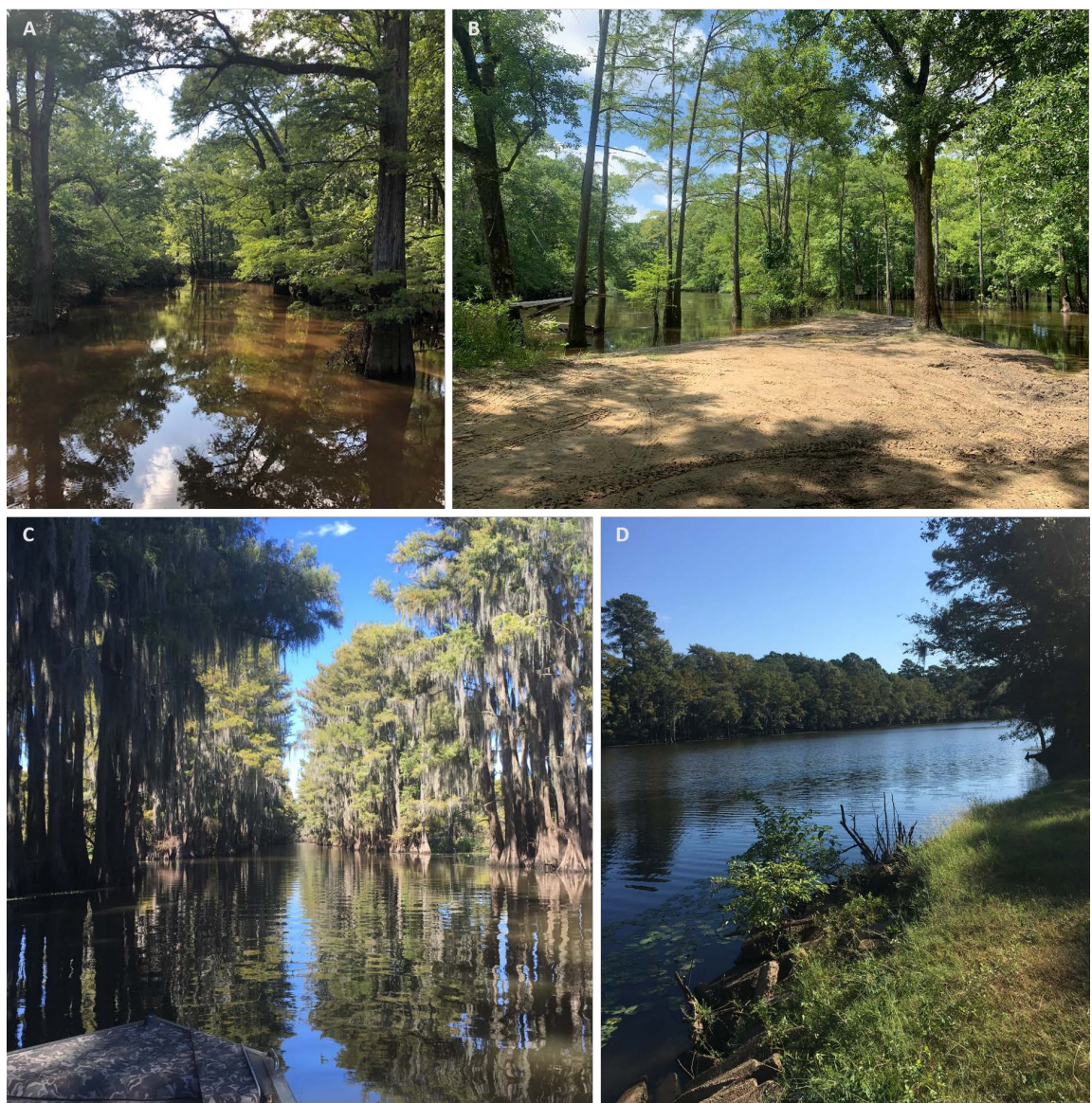

Figure 2. Black Cypress Bayou (A) at the upper reaches in southern Cass County. Confluence of Black Cypress and Big Cypress bayous (B) east of the city of Jefferson. Caddo Lake (C) is home to densely wooded bald cypress along the shoreline and islands. Big Cypress Bayou (D) east of the Highway 43 bridge as it flows towards Caddo Lake.

There has been relatively little hydrologic and geomorphologic research for the Caddo Lake watershed in terms of published reports and journal articles. The main source of information regarding the hydrologic, physicochemical, and contaminant concerns are the data archives collected and managed by government agencies such as the United States Geological Survey, the Corp of Engineers, Texas Commission on Environmental Quality, and the Texas Water Development Board. Within the watershed, the now-closed Longhorn Army Ammunition Plant has been the major focus of research regarding trace element transport. Some researchers have attempted to determine sedimentation rates in Caddo Lake in order to pinpoint specific processes or events that may have contributed to the current conditions. Wilson (2003) documented the occurrence and trends of selected contaminants in sediment cores from Caddo Lake, with an emphasis on mercury, but did not address watershed contributions. Lisantti (2001) used gamma ray spectroscopy to measure modern sedimentation rates using the depth profile of 137Cs in sample cores from Caddo Lake, but most of the samples were collected from the eastern portion of the lake.

Over the past twenty years, Caddo Lake has reported some of the highest mer- 
cury concentrations in fresh water fish in the state. Twidwell (2000) studied the relationships between mercury concentration in fish and physicochemical variables in water and sediment in East Texas waterbodies, including Caddo Lake. No significant correlations were observed between standardized mercury concentrations in fish and mercury concentrations in water or sediment, suggesting that mercury concentrations in water and sediment are not nearly as important as geochemical in-reservoir and lake processes. Crowe (1998) assessed the geographic occurrence of mercury in sediment, water and fish samples from two East Texas river basins. Mercury concentrations in fish tissue were positively correlated to size, but no definitive correlation was observed between mercury accumulations and sedimentation processes.

Since 1995, Caddo Lake and some of its major tributaries have been included on the State of Texas Clean Water Act 303(d) list by the Texas Commission on Environmental Quality (TCEQ) for impairment due to mercury content in edible tissue, depressed dissolved oxygen, base metal concentrations, and low $\mathrm{pH}$ values (USGS, 1995; TCEQ, 2020). Recent research in the Caddo Lake watershed has indicated higher mercury concentrations near the confluence of Big Cypress and Black Cypress bayous and near the city of Jefferson (Watkins, 2018). Elevated levels of arsenic $(\mathrm{As})$, barium $(\mathrm{Ba})$, copper $(\mathrm{Cu})$, lead $(\mathrm{Pb})$, manganese $(\mathrm{Mn})$, mercury $(\mathrm{Hg})$, and zinc $(\mathrm{Zn})$ have been reported near the city of Jefferson (Faulkner \& Stafford, 2019). The information in the following article is the culmination the authors' multi-year studies characterizing base metal concentrations in stream water and sediments in Big Cypress, Little Cypress, and Black Cypress bayous in order to provide a better understanding of metal transport in the Caddo Lake watershed, and potential watershed contribution to the impairment of Caddo Lake.

\section{Hydrogeologic Setting}

The Caddo Lake watershed is underlain by Eocene-aged rocks and sediments associated with lithologies from the Wilcox and Claiborne groups. These layers were deposited as the Gulf of Mexico shoreline fluctuated during the Paleogene Period (Galloway et al., 2000), and the outcrop pattern and distribution of the sedimentary lithologies in East Texas are nearly parallel with the pattern of distribution of modern sediments in the Gulf of Mexico and its adjacent coastal plain (Shaw, 2006). These shoreline fluctuations caused interbedded fluvial and deltaic sediments to be deposited, including lignite seams associated with anoxic coastal lagoons and hardwood swamps (Fisher, 1964). Long periods of erosion and shoreline regression were followed by brief periods of deposition and transgression creating thick sequences of undivided friable sandstones, mudstones, and lignite seams of the Wilcox Group and lower Claiborne Group lithologies (Figure 3). In the study area, the Wilcox Group is overlain by the Reklaw Formation; an evenly bedded calcareous mudstone that contains glauconitic lenses, lignite, and ironstone concretions; and the Queen City Sand. These units are exposed 


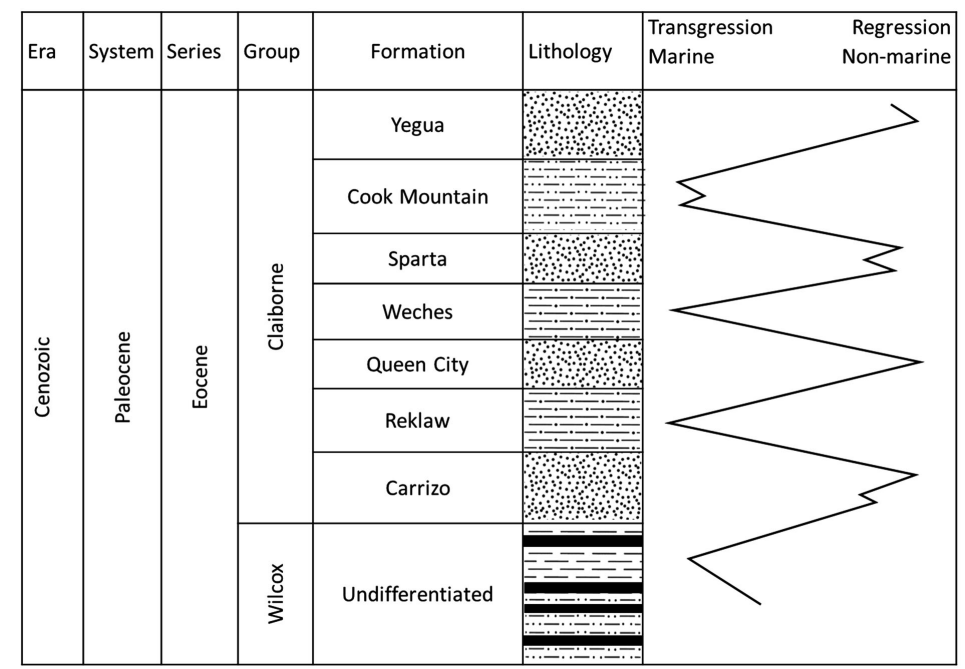

Figure 3. Stratigraphic column and sea level curve for the Wilcox and Claiborne group lithologies in east Texas. The Caddo Lake watershed is underlain by the Wilcox and lower Claiborne formations

at the surface in northeastern Texas and prograde to the south in the subsurface toward the Texas Gulf Coast (Figure 4).

The Wilcox Group is of special interest because it hosts extractable seams of interbedded lignite coal, which contain appreciable concentrations of heavy metals. Historically, this lignite has been mined and processed to produce electricity at numerous coal-fired power plants in East Texas. The Reklaw Formation of the Claiborne Group is also known to host some heavy metals including uranium $(\mathrm{U})$, thorium $(\mathrm{Th})$, and $\mathrm{As}$; and an apprecible pyrite $\left(\mathrm{FeS}_{2}\right)$ concentration, which can contribute to acidic conditions in water, soils and sediments. When pyrite is in contact with the atmosphere and/or oxygenated waters, acid weathering contributes to sulfate production, lower $\mathrm{pH}$ values, and potentially aids in the mobility of metals in the aqueous environment (Shaw, 2006). The watershed tributaries, Big Cypress, Black Cypress, and Little Cypress bayous, flow in an eastward direction through the Interior Coastal Plains of Texas, characterized by low rolling hills and heavily wooded terrain covered by a mix of pines and hardwoods (Eargle, 1968) and empty into the western arm of Caddo Lake (Figure 4).

Hydrologically, the Caddo Lake watershed has undergone several significant changes. In the early 1900s, the US government established a water navigation plan to dredge the channels in order to allow boats up river to access the city of Jefferson. In 1914, an earthen dam was constructed that raised the water level of the lake (Albertson \& Dunbar, 1993). In 1960, with the completion of Lake O' the Pines 90 kilometers upstream, environmental flows in the watershed were substantially altered, reducing the flow by about $5 \%$ annually (Winemiller et al., 2005). Present day, Caddo Lake and its watershed includes one of the largest bald cypress ecosystems in the United States and serves as the primary source of drinking water for several surrounding communities (Hartung, 1983; Figure 2). 


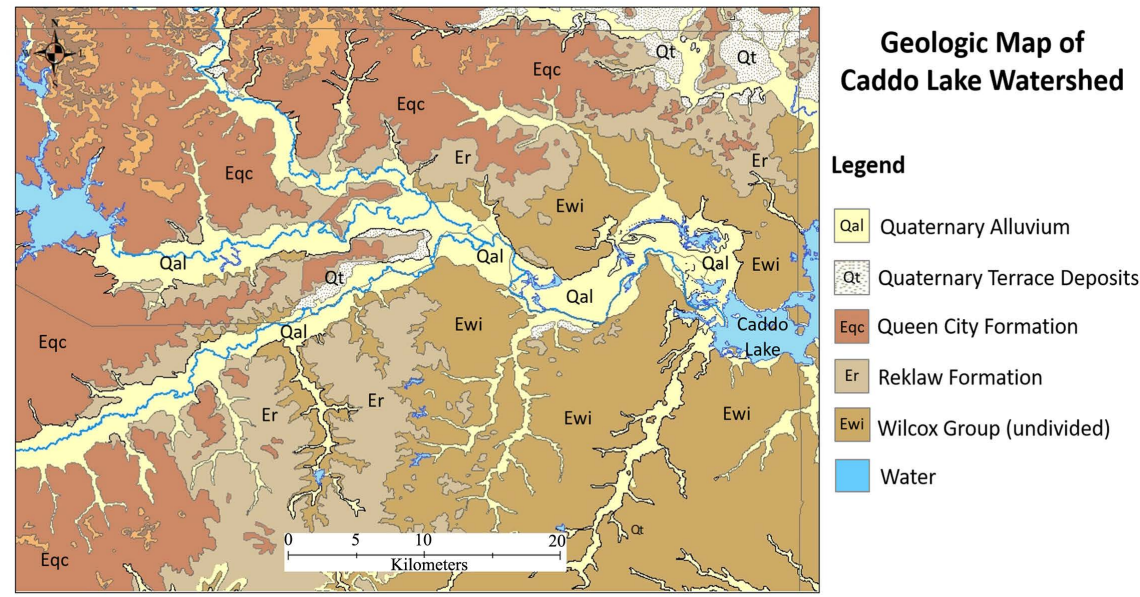

Figure 4. Geologic map of the Caddo Lake watershed (Geologic Database of Texas, Texas Natural Resources Information System, accessed June 12, 2020).

\section{Materials and Methods}

\subsection{Study Area}

In order to determine the geochemical characteristics of stream water and sediments in the Caddo Lake watershed, 116 sediment and 58 water samples were collected from 29 sampling locations in Big Cypress, Black Cypress, and Little Cypress bayous from October 2016 to July 2019 (Figure 5). A variety of methodologies were employed in order to characterize metal concentrations including geochemical analyses of stream water samples, metal digestion and $\mathrm{Hg}$ analyses of sediment cores, and particle size distribution. Elements of interest were spatially delineated to determine natural and anthropogenic contributions to the geochemical environment of the Caddo Lake watershed.

\subsection{Water Sampling}

Water sampling was conducted in Little Cypress and Big Cypress bayous in October 2016 and April 2017; and in Black Cypress and Big Cypress bayous during May 2018 and July 2019. During all sampling events, physicochemical parameters of stream water were measured in the field using an Oakton PCD 650 multi-meter probe to determine $\mathrm{pH}$, temperature $\left({ }^{\circ} \mathrm{C}\right)$, dissolved oxygen $(\%)$, and conductivity $(\mu \mathrm{s} / \mathrm{cm})$. All water samples were collected in $500 \mathrm{ml}$ Nalgene water sampler bottles below the water surface. The water samples were labeled and placed on ice, then transported to the laboratory for analyses.

Analyses were conducted by the SFA Soil, Plant, and Water Analyses Laboratory. Anions were determined using a Dionex 1000 Ion Chromatograph and by titration (total carbonate). Total and dissolved metals were determined using a Thermo Scientific iCAP 7400 ICP Analyzer. Results from water analyses were compared to the Texas Water Development Board (TWDB) Maximum Contaminant Levels for Groundwater Standards and the Environmental Protection Agency (EPA) Drinking Water Standards. 


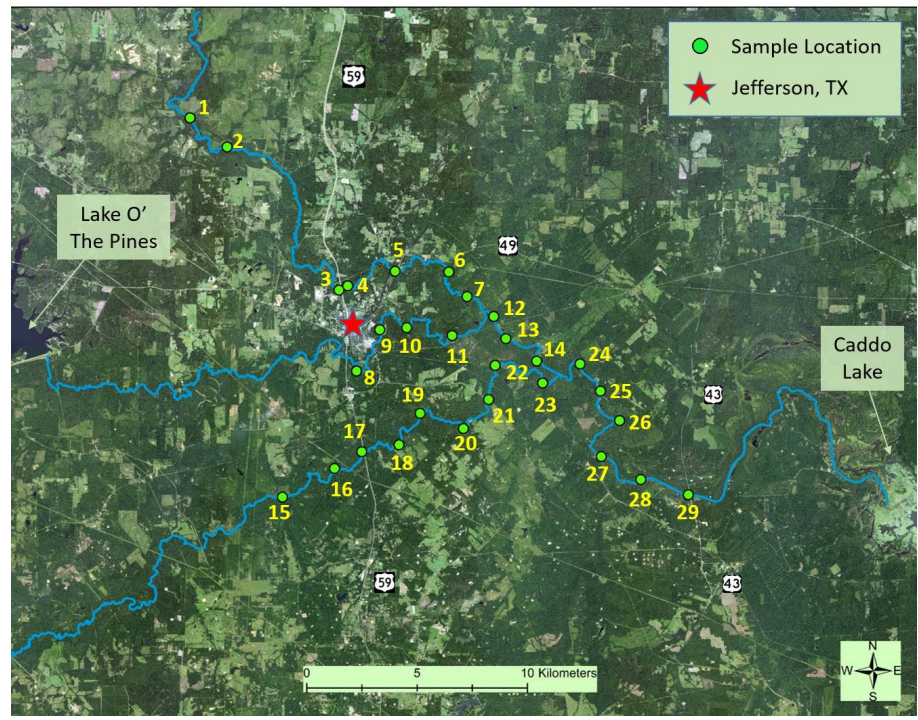

Figure 5. Satellite image of study area with sampling locations $(n=29)$, the city of Jefferson, major highways and waterbodies identified. Imagery from Texas Natural Resources Information System (TNRIS), accessed June 12, 2020.

\subsection{Sediment Sampling}

During the study, sediment sampling was conducted in October 2016, April 2017, May 2018, and July 2019. Sediment samples were collected by inserting a $15-\mathrm{cm}$ plastic sediment core sleeve into the stream bed; in areas where the sediments were waterlogged to capture with sediment core sleeves, a hand trowel and plastic bags were used to collect stream sediment samples. The samples were immediately labeled and stored on ice, then transported to the laboratory and placed in a freezer for a minimum of 48 hours to allow the sediments to stabilize.

Sediment analyses were conducted by the SFA Soil, Plant, and Water Analyses Laboratory using EPA Method 3050B, Acid Digestion of Sediments, Sludge, and Soils (Sampling events 2016, 2017, and 2018; EPA, 2019a) and by Pace Analytical Laboratories using EPA Method 6010C (Sampling event 2019; EPA, 2016b) to determine trace elements. All samples were prepared following EPA protocols and analyzed using Inductively Coupled Plasma Atomic Emission Spectroscopy (ICP-AES) to determine metal concentrations. Mercury analyses were conducted using EPA Method 7471B (EPA, 2019b), approved for measuring total $\mathrm{Hg}$ in soils, sediments, and sludge-type materials using a cold-vapor technique. All $\mathrm{Hg}$ samples were freeze-dried prior to testing to remove excess water and prevent the volatilization of $\mathrm{Hg}$ compounds. Results from sediment analyses were compared to the EPA April 2020 Regional Screening Level Resident Soil Table (EPA, 2020b) to determine potential contaminant levels for $\mathrm{Cu}, \mathrm{Hg}, \mathrm{Pb}$, and $\mathrm{Zn}$.

\subsection{Characterization of Stream Sediments}

Particle size analyses were conducted to determine sediment size distribution and more thoroughly characterize geologic sediments at the sampling locations. Additional $15-\mathrm{cm}$ sediment cores were collected from each location for the Oc- 
tober 2016 and July 2019 sampling events. These 58 samples were used to determine the percent of sand, clay, and silt sediment particles at each location using the Bouyoucos Method (Ashworth et al., 2001).

\section{Results}

\subsection{Physicochemical Parameters}

All three stream segments sampled during this study were listed as impaired by TCEQ for not meeting established water quality standards (TCEQ, 2020). Big Cypress Bayou downstream of Lake O' the Pines was listed for low $\mathrm{pH}$, depressed dissolved oxygen, and elevated mercury concentrations in edible tissue. Black Cypress and Little Cypress bayous were listed for elevated bacteria levels and depressed dissolved oxygen. Black Cypress Bayou has been documented to have elevated copper concentrations in the water and mercury concentrations in edible tissue. Mean values for all physicochemical parameters are reported in Table 1 .

During the study period, all $\mathrm{pH}$ values ranged from 5.8 to 7.6, within normal limits for natural water bodies. Temperature fluctuated based on ambient conditions, the depth of the stream channel, radiant energy, and recent weather events. Conductivity for all measurements was less than $200 \mu \mathrm{s} / \mathrm{cm}$ and dissolved oxygen (DO\%) ranged from $76.50 \%-92.03 \%$. Water clarity ranged from murky to muddy, with a significant suspended sediment load in the upper reaches. Clarity increased downstream in Big Cypress Bayou below the confluence with Black Cypress and Little Cypress bayous (EPA, 2016a; Figure 2).

\subsection{Geochemical Analyses of Stream Waters}

Water samples were analyzed for the standard suite of cations and anions used to characterize natural waters and base metals including cadmium, copper, lead, mercury, tin, and zinc. Results for water analyses reported uniform geochemical concentrations reflective of the lithologies over which they flow, their geomorphic environment, and the discharge variability associated with seasonal weather patterns. Geochemical analyses of stream water reported a well-mixed system; major cations of most samples were enriched in sodium $(\mathrm{Na})$ and potassium $(\mathrm{K})$ with respect to calcium $(\mathrm{Ca})$ and magnesium $(\mathrm{Mg})$, with $\mathrm{Ca}$ more prominent than $\mathrm{Mg}$. Anions reported a mixed-fluid system with bicarbonate $\left(\mathrm{HCO}_{3}\right)$ and chlorine $(\mathrm{Cl})$ more prominent than sulfate $\left(\mathrm{SO}_{4}\right)$. The pyrite associated with the Reklaw Formation would be subject to acid sulfate weathering (Shaw, 2006), but the buffering systems supported by $\mathrm{HCO}_{3}$ and clay minerals have neutralized these conditions (Figure 6).

Metals reported in stream water show $\mathrm{Zn}$ concentrations enriched with respect to $\mathrm{Cu}$ and $\mathrm{Pb}$ (Table 2). The Texas Commission on Environmental Quality (TCEQ) has listed Black Cypress Bayou as impaired for $\mathrm{Cu}$ since 1995. Natural waters free from contamination usually contain less than $10 \mathrm{ppb}$ of $\mathrm{Cu}$ and eight of the samples from the watershed exceeded this threshold, but no water sample 
M. S. Faulkner et al.

Table 1. Bayou name, sampling dates, and mean values $(n=2$ for each site) for physicochemical parameters reported at sampling locations in the Caddo Lake watershed.

\begin{tabular}{|c|c|c|c|c|c|c|c|}
\hline \multirow{2}{*}{$\begin{array}{l}\text { Sampling } \\
\text { Location }\end{array}$} & \multirow{2}{*}{ Bayou } & \multirow{2}{*}{$\begin{array}{c}\text { Sampling } \\
\text { Date } 1\end{array}$} & \multirow{2}{*}{$\begin{array}{c}\text { Sampling } \\
\text { Date } 2\end{array}$} & \multicolumn{4}{|c|}{ Mean Values } \\
\hline & & & & $\mathrm{pH}$ & $\mathrm{T}\left({ }^{\circ} \mathrm{C}\right)$ & Cond $(\mu \mathrm{s} / \mathrm{cm})$ & DO\% \\
\hline 1 & Black & May-18 & Jul-19 & 6.34 & 17.23 & 282.73 & 82.17 \\
\hline 2 & Black & May-18 & Jul-19 & 6.61 & 23.03 & 123.50 & 88.76 \\
\hline 3 & Black & May-18 & Jul-19 & 6.66 & 18.90 & 51.31 & 85.60 \\
\hline 4 & Black & May-18 & Jul-19 & 6.71 & 17.50 & 46.71 & 88.46 \\
\hline 5 & Black & May-18 & Jul-19 & 6.75 & 20.27 & 132.40 & 80.86 \\
\hline 6 & Black & May-18 & Jul-19 & 7.01 & 23.07 & 118.71 & 90.90 \\
\hline 7 & Black & May-18 & Jul-19 & 7.22 & 20.90 & 156.43 & 89.20 \\
\hline 8 & Big & Oct-16 & Apr-17 & 7.36 & 21.07 & 134.53 & 94.63 \\
\hline 9 & Big & Oct-16 & Apr-17 & 7.20 & 19.96 & 84.95 & 84.30 \\
\hline 10 & Big & Oct-16 & Apr-17 & 6.78 & 17.86 & 198.43 & 85.70 \\
\hline 11 & Big & Oct-16 & Apr-17 & 6.56 & 18.13 & 181.36 & 87.57 \\
\hline 12 & Big & Oct-16 & Apr-17 & 6.57 & 21.16 & 193.63 & 88.50 \\
\hline 13 & Big & Oct-16 & Apr-17 & 6.27 & 20.70 & 108.57 & 86.30 \\
\hline 14 & Big & Oct-16 & Apr-17 & 6.21 & 17.85 & 199.94 & 76.75 \\
\hline 15 & Little & Oct-16 & Apr-17 & 6.60 & 21.90 & 120.35 & 76.50 \\
\hline 16 & Little & Oct-16 & Apr-17 & 6.76 & 20.60 & 165.44 & 87.07 \\
\hline 17 & Little & Oct-16 & Apr-17 & 6.82 & 20.20 & 118.02 & 86.20 \\
\hline 18 & Little & Oct-16 & Apr-17 & 7.11 & 19.80 & 108.09 & 86.23 \\
\hline 19 & Little & Oct-16 & Apr-17 & 7.01 & 19.70 & 91.34 & 88.90 \\
\hline 20 & Little & Oct-16 & Apr-17 & 7.08 & 20.13 & 157.07 & 80.60 \\
\hline 21 & Little & Oct-16 & Apr-17 & 7.03 & 22.00 & 112.34 & 92.03 \\
\hline 22 & Little & Oct-16 & Apr-17 & 6.71 & 20.06 & 89.86 & 88.73 \\
\hline 23 & Little & Oct-16 & Apr-17 & 6.75 & 19.00 & 132.12 & 90.46 \\
\hline 24 & Big & Apr-17 & Jul-19 & 6.26 & 19.37 & 123.14 & 88.54 \\
\hline 25 & Big & Apr-17 & Jul-19 & 7.54 & 19.54 & 134.46 & 89.63 \\
\hline 26 & Big & Apr-17 & Jul-19 & 6.88 & 18.61 & 122.28 & 90.45 \\
\hline 27 & Big & Apr-17 & Jul-19 & 6.94 & 20.22 & 146.59 & 88.48 \\
\hline 28 & Big & Apr-17 & Jul-19 & 7.37 & 19.84 & 132.88 & 89.63 \\
\hline 29 & Big & Apr-17 & Jul-19 & 7.13 & 19.56 & 128.79 & 88.62 \\
\hline
\end{tabular}


Table 2. Dissolved metals in stream water samples ( $\mathrm{n}=2$ for each site) from Little Cypress, Big Cypress, and Black Cypress bayous.

\begin{tabular}{|c|c|c|c|c|c|c|c|}
\hline \multirow{2}{*}{$\begin{array}{l}\text { Sampling } \\
\text { Location }\end{array}$} & \multirow{2}{*}{ Bayou } & \multirow{2}{*}{$\begin{array}{c}\text { Sampling } \\
\text { Date } 1\end{array}$} & \multirow{2}{*}{$\begin{array}{c}\text { Sampling } \\
\text { Date } 2\end{array}$} & \multicolumn{4}{|c|}{ Mean Concentration (ppb) } \\
\hline & & & & $\mathrm{Cu}$ & $\mathrm{Hg}$ & $\mathrm{Pb}$ & $\mathrm{Zn}$ \\
\hline 1 & Black & May-18 & Jul-19 & 9.91 & 0.50 & 5.13 & 11.91 \\
\hline 2 & Black & May-18 & Jul-19 & 11.04 & 1.52 & 5.36 & 10.93 \\
\hline 3 & Black & May-18 & Jul-19 & 13.14 & 0.90 & 7.46 & 16.34 \\
\hline 4 & Black & May-18 & Jul-19 & 8.59 & 0.67 & 6.85 & 11.78 \\
\hline 5 & Black & May-18 & Jul-19 & 6.34 & 0.55 & 3.42 & 6.89 \\
\hline 6 & Black & May-18 & Jul-19 & 7.97 & 0.46 & 6.18 & 9.21 \\
\hline 7 & Black & May-18 & Jul-19 & 8.07 & 0.37 & 9.04 & 7.28 \\
\hline 8 & Big & Oct-16 & Apr-17 & 11.64 & 0.28 & 5.61 & 10.82 \\
\hline 9 & Big & Oct-16 & Apr-17 & 13.81 & 0.30 & 3.63 & 12.63 \\
\hline 10 & Big & Oct-16 & Apr-17 & 6.89 & 7.25 & 9.43 & 38.72 \\
\hline 11 & Big & Oct-16 & Apr-17 & 13.71 & 0.63 & 3.00 & 20.59 \\
\hline 12 & Big & Oct-16 & Apr-17 & 11.31 & 0.36 & 6.56 & 22.57 \\
\hline 13 & Big & Oct-16 & Apr-17 & 12.42 & 0.37 & 5.72 & 17.38 \\
\hline 14 & Big & Oct-16 & Apr-17 & 7.66 & 0.87 & 5.26 & 13.70 \\
\hline 15 & Little & Oct-16 & Apr-17 & 10.26 & 0.84 & 3.44 & 10.96 \\
\hline 16 & Little & Oct-16 & Apr-17 & 9.13 & 0.34 & 5.20 & 16.62 \\
\hline 17 & Little & Oct-16 & Apr-17 & 6.20 & 0.18 & 9.68 & 17.34 \\
\hline 18 & Little & Oct-16 & Apr-17 & 8.50 & 0.49 & 5.72 & 12.05 \\
\hline 19 & Little & Oct-16 & Apr-17 & 7.99 & 1.42 & 9.56 & 30.76 \\
\hline 20 & Little & Oct-16 & Apr-17 & 7.24 & 0.26 & 1.71 & 6.07 \\
\hline 21 & Little & Oct-16 & Apr-17 & 7.69 & 0.84 & 5.97 & 13.37 \\
\hline 22 & Little & Oct-16 & Apr-17 & 8.61 & 0.28 & 6.34 & 11.68 \\
\hline 23 & Little & Oct-16 & Apr-17 & 9.97 & 0.72 & 7.90 & 10.11 \\
\hline 24 & Big & Apr-17 & Jul-19 & 5.81 & 0.34 & 1.65 & 4.76 \\
\hline 25 & Big & Apr-17 & Jul-19 & 7.49 & 0.33 & 5.83 & 12.30 \\
\hline 26 & Big & Apr-17 & Jul-19 & 7.28 & 0.34 & 2.28 & 5.02 \\
\hline 27 & Big & Apr-17 & Jul-19 & 10.38 & 0.79 & 5.87 & 13.67 \\
\hline 28 & Big & Apr-17 & Jul-19 & 4.91 & 0.25 & 7.51 & 6.76 \\
\hline 29 & Big & Apr-17 & Jul-19 & 11.25 & 0.23 & 4.72 & 13.66 \\
\hline
\end{tabular}

exceeded the actionable threshold of $1300 \mathrm{ppb}$ (Figure 7(A) and Figure 7(B)). Most of the higher $\mathrm{Cu}$ concentrations are located in Black Cypress and Big $\mathrm{Cy}-$ press bayous, near their confluence. 


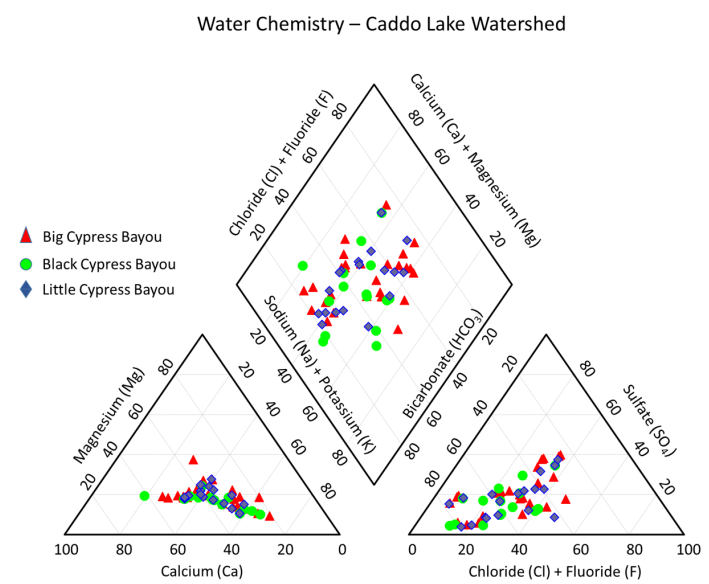

Figure 6. Piper diagram for stream water chemistry of major cations and anions. Data represents a well-mixed system with most samples enriched in sodium $(\mathrm{Na})$ and potassium $(\mathrm{K})$ with respect to calcium $(\mathrm{Ca})$ and magnesium $(\mathrm{Mg})$, with Ca more prominent than $\mathrm{Mg}$. Anions reported a mixed-fluid system with bicarbonate $\left(\mathrm{HCO}_{3}\right)$ and chlorine $(\mathrm{Cl})$ more prominent than sulfate $\left(\mathrm{SO}_{4}\right)$.

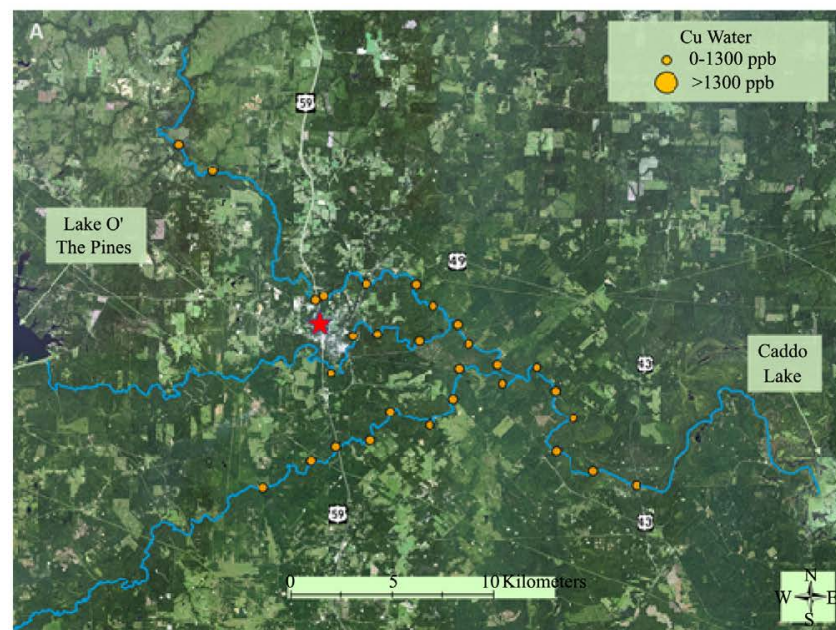

B

B

Copper Concentration in Stream Water

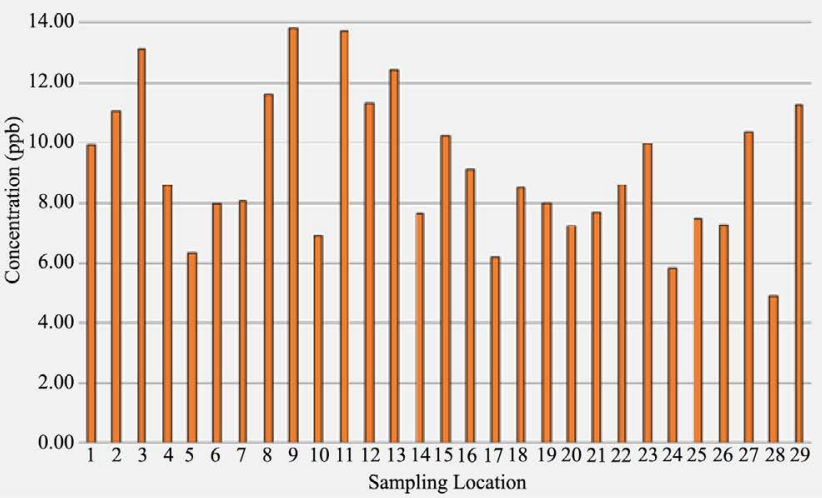

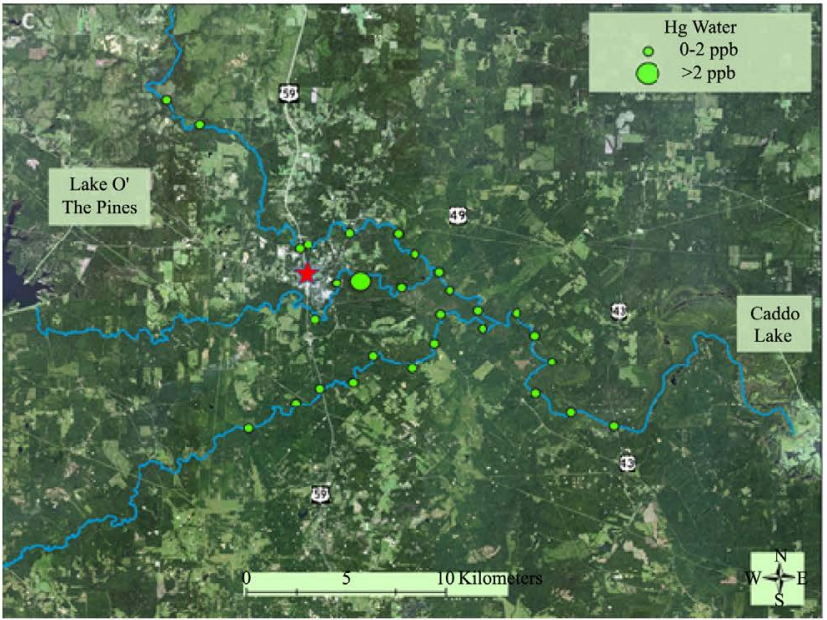

Mercury Concentration in Stream Water

D

16.00

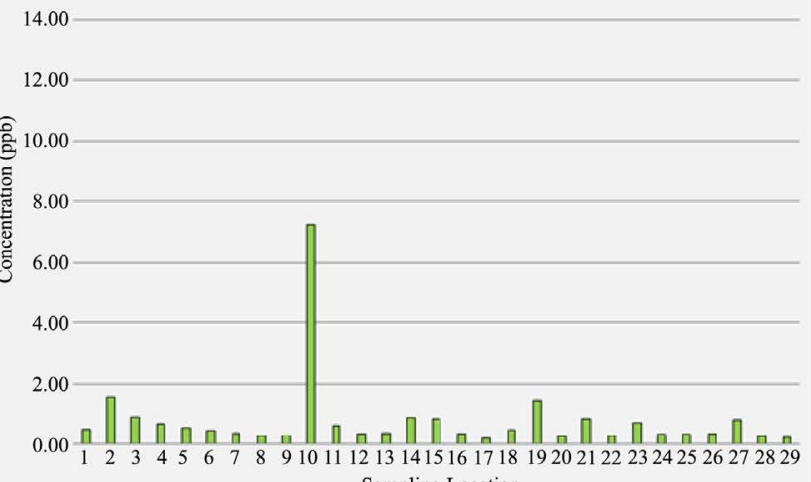

Figure 7. Copper concentrations in stream water ((A) and (B)). Although several samples exceeded EPA drinking water standards of $10 \mathrm{ppb}$, no samples reported concentrations that met the impaired threshold. Mercury concentrations in stream water are shown in (C) and (D). Only one sample exceeded the $2 \mathrm{ppb}$ standard, all other samples reported concentrations below the impairment threshold. 
In regards to mercury, one water sample in Big Cypress Bayou exceeded the impairment threshold of $2 \mu \mathrm{g} / \mathrm{l}$ for $\mathrm{Hg}$ near the city of Jefferson (7.25 ppb), all other samples were below the actionable standard (Figure $7(\mathrm{C})$ and Figure 7(D)). By the time Big Cypress Bayou empties into the western arm of Caddo Lake, $\mathrm{Hg}$ concentrations are much lower $(0.23 \mathrm{ppb})$. All lead (Figure 8(A) and Figure 8(B)) and zinc (Figure 8(C) and Figure 8(D)) concentrations in stream water were below TWDB impairment value for groundwater standards and the EPA 2020 National Drinking Water Standards (Pb-15 ppb and Zn-5000 ppb; EPA, 2020a). All concentrations for cadmium and tin were below detection limits.

\subsection{Geochemical Analyses of Stream Sediments}

Base metals reported in stream sediments included $\mathrm{Cu}, \mathrm{Hg}, \mathrm{Pb}$, and $\mathrm{Zn}$. Copper concentrations were negligible at all sampling locations, including Black Cypress Bayou (Ertons \& Faulkner, 2020). All sediment samples contained less than 6 ppb copper, well below the EPA impairment threshold of $100 \mathrm{ppb}$ for soils and
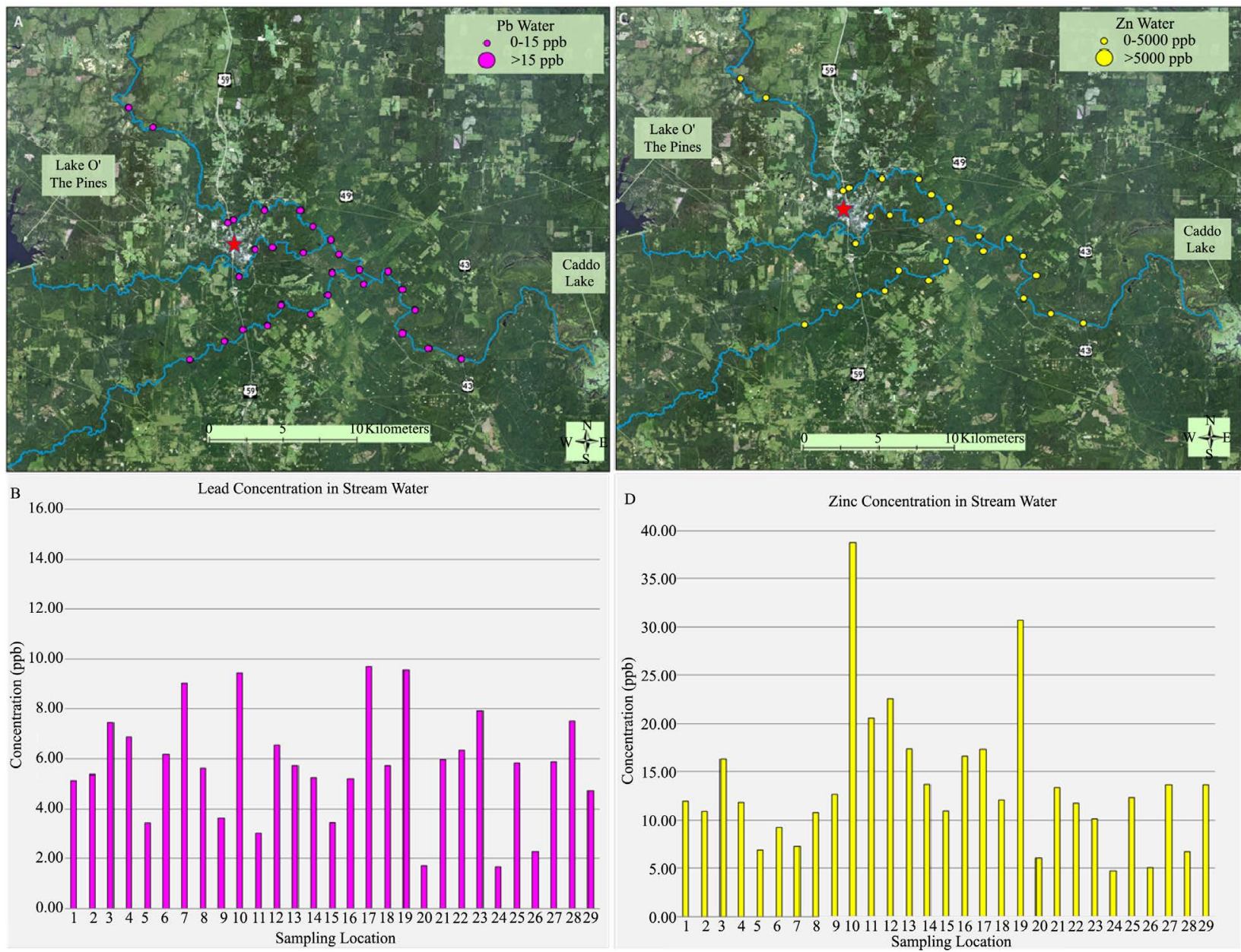

Figure 8. Lead concentrations in stream water ((A) and (B)). All samples reported concentrations below the impairment threshold. Zinc concentrations in stream water are shown in (C) and (D). All samples reported concentrations below the impairment threshold. 
sediments (EPA, 2020b). The highest reported copper in Black Cypress Bayou (4.78 ppb) occurred north of the confluence with Big Cypress Bayou; Little Cypress Bayou reported two of the higher values (4.68 ppb and $4.25 \mathrm{ppb}$ ), and Big Cypress Bayou reported one location with $6.41 \mathrm{ppb}$. Measurements fluctuated throughout the study area, with higher values recorded near major highways and near the confluence of Little Cypress and Big Cypress bayous (Figure 9(A) and Figure 9(B)).

Twenty-one of the sediment sampling locations reported mercury concentrations above the EPA impairment threshold of $0.3 \mathrm{ppb}$ for soils and sediments (EPA, 2020b). All stream systems reported elevated mercury, with the highest concentrations found in Black Cypress Bayou (6.15 ppb) near the confluence with Big Cypress Bayou and in Little Cypress Bayou (11.20 ppb) near the confluence with Big Cypress Bayou. Mercury concentrations decreased downstream as Big Cypress Bayou flowed toward Caddo Lake (Figure 9(C) and Figure 9(D)).

Lead concentrations in Black Cypress Bayou stream sediments were higher near Highway 59 (7.81 ppb and $7.65 \mathrm{ppb}$ ), and continued to decrease as the stream
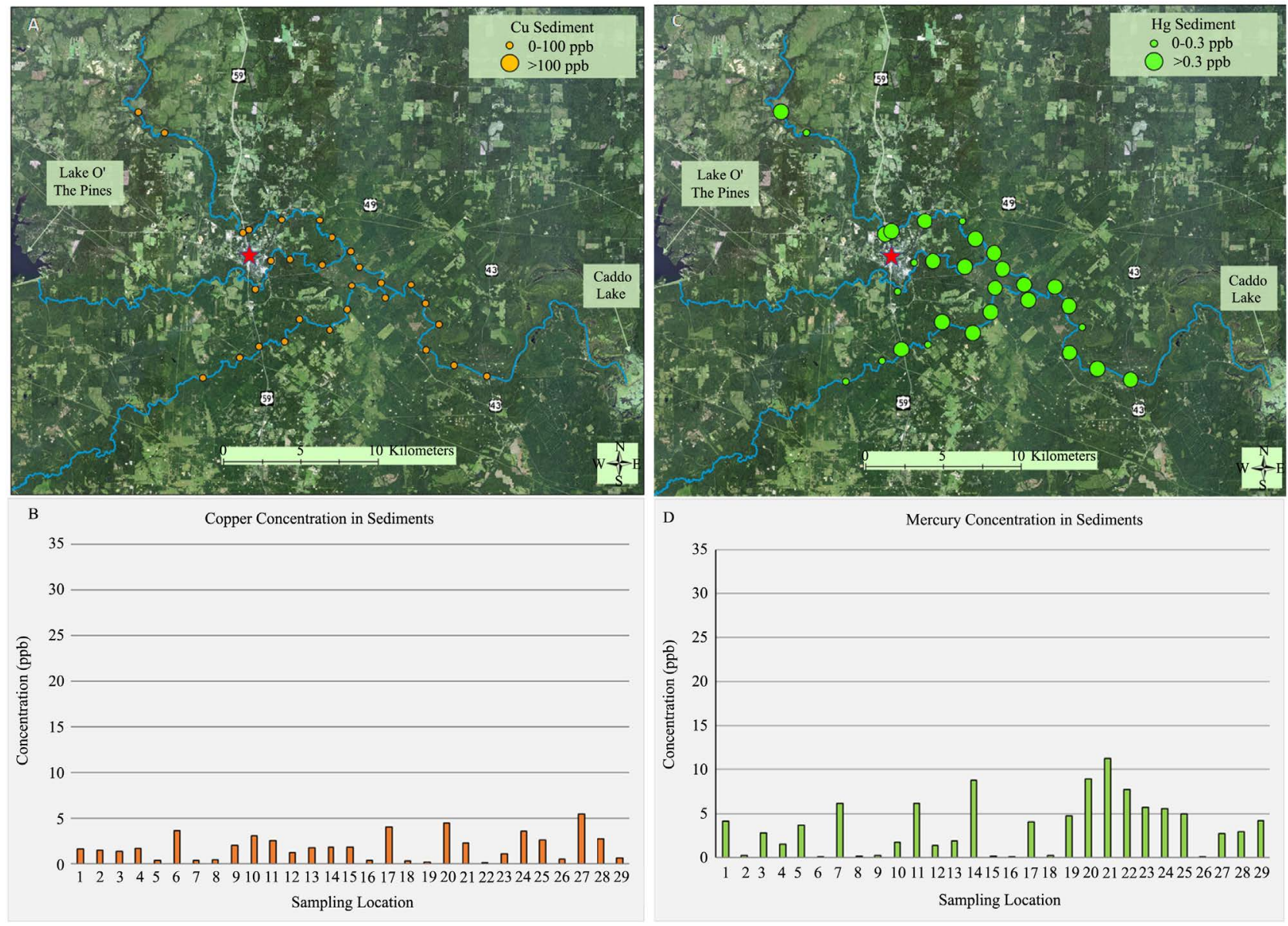

Figure 9. Copper concentrations in sediments ((A) and (B)). All samples reported concentrations below the impairment threshold. Mercury concentrations in sediments are shown in (C) and (D). Twenty-one of 29 samples reported concentrations above the impairment threshold. 
flowed toward the confluence with Big Cypress Bayou (Ertons \& Faulkner, 2020). Lead concentrations in Big Cypress Bayou were higher near the city of Jefferson (9.91 ppb and $8.22 \mathrm{ppb}$ ) and lowered to $3.95 \mathrm{ppm}$ before it entered Caddo Lake. Little Cypress Bayou reported lower lead values overall, with the highest concentration found near Highways 59 (7.37 ppb). No sampling locations reported lead concentrations above the impairment threshold of $200 \mathrm{ppb}$ (EPA, 2020b; Figure 10(A) and Figure 10(B)).

Zinc concentrations spiked near all major highways; in Black Cypress Bayou, the highest readings were found at sampling locations near Highway 59 (27.90 ppb and $22.49 \mathrm{ppb}$ ) and Highway 49 (28.64 ppb). Concentrations in Big Cypress Bayou were lower overall, but peaked near the Highway 43 Bridge (18.28 ppb and $18.10 \mathrm{ppb}$ ). Little Cypress Bayou reported lower zinc concentrations at sampling locations, with the highest values reported west of Highway 59 (14.55 ppb) and near the confluence of Little Cypress and Big Cypress bayous (17.94 ppb and $18.25 \mathrm{ppb})$. No sampling locations reported zinc concentrations above the impairment threshold of $500 \mathrm{ppb}$ (EPA, 2020b; Figure 10(C) and Figure 10(D); Table 3).

\subsection{Particle Size Analyses}

The particle size distribution of the sediment samples were uniform throughout
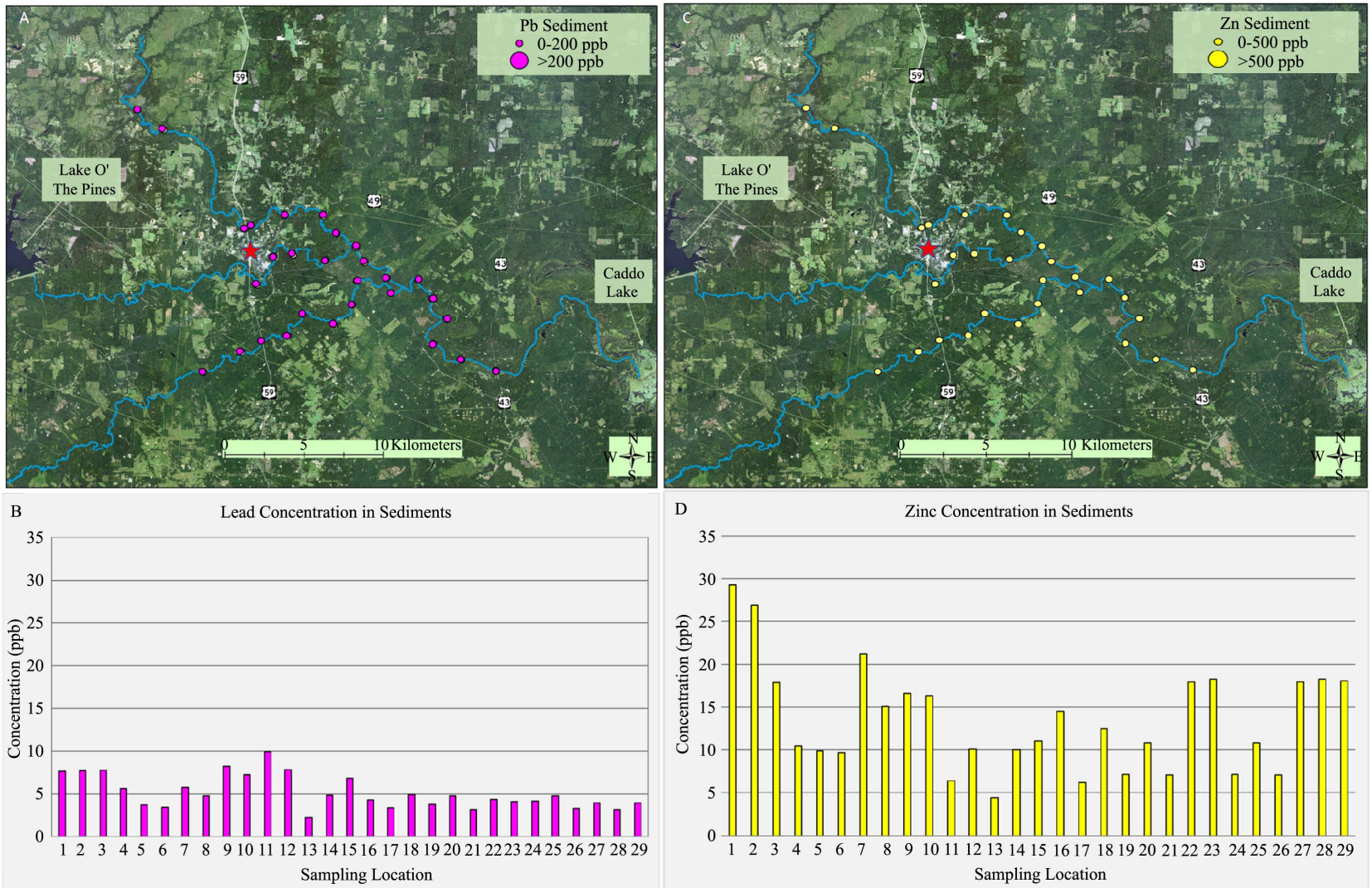

Figure 10. Lead ((A) and (B)) and zinc ((C) and (D)) concentrations in sediments. All samples were below the impairment threshold. 
Table 3. Metals in stream sediment samples ( $\mathrm{n}=4$ for each site) from Little Cypress, Big Cypress, and Black Cypress bayous.

\begin{tabular}{|c|c|c|c|c|c|c|c|c|c|}
\hline \multirow{2}{*}{$\begin{array}{l}\text { Sampling } \\
\text { Location }\end{array}$} & \multirow{2}{*}{ Bayou } & \multirow{2}{*}{$\begin{array}{c}\text { Sampling } \\
\text { Date } 1\end{array}$} & \multirow{2}{*}{$\begin{array}{c}\text { Sampling } \\
\text { Date } 2\end{array}$} & \multirow{2}{*}{$\begin{array}{c}\text { Sampling } \\
\text { Date } 3\end{array}$} & \multirow{2}{*}{$\begin{array}{l}\text { Sampling } \\
\text { Date } 4\end{array}$} & \multicolumn{4}{|c|}{ Mean Concentration (ppb) } \\
\hline & & & & & & $\mathrm{Cu}$ & $\mathrm{Hg}$ & $\mathrm{Pb}$ & $\mathrm{Zn}$ \\
\hline 1 & Black & Oct-16 & Apr-17 & May-18 & Jul-19 & 2.08 & 0.36 & 7.62 & 29.29 \\
\hline 2 & Black & Oct-16 & Apr-17 & May-18 & Jul-19 & 2.07 & 0.13 & 7.70 & 26.85 \\
\hline 3 & Black & Oct-16 & Apr-17 & May-18 & Jul-19 & 2.16 & 0.41 & 7.81 & 17.90 \\
\hline 4 & Black & Oct-16 & Apr-17 & May-18 & Jul-19 & 4.73 & 0.46 & 5.65 & 10.49 \\
\hline 5 & Black & Oct-16 & Apr-17 & May-18 & Jul-19 & 4.43 & 0.49 & 3.73 & 9.87 \\
\hline 6 & Black & Oct-16 & Apr-17 & May-18 & Jul-19 & 4.60 & 0.26 & 3.43 & 9.64 \\
\hline 7 & Black & Oct-16 & Apr-17 & May-18 & Jul-19 & 4.21 & 0.42 & 5.80 & 21.18 \\
\hline 8 & Big & Oct-16 & Apr-17 & May-18 & Jul-19 & 3.37 & 0.23 & 4.77 & 15.04 \\
\hline 9 & Big & Oct-16 & Apr-17 & May-18 & Jul-19 & 3.72 & 0.17 & 8.22 & 16.57 \\
\hline 10 & Big & Oct-16 & Apr-17 & May-18 & Jul-19 & 6.41 & 0.42 & 7.26 & 16.28 \\
\hline 11 & Big & Oct-16 & Apr-17 & May-18 & Jul-19 & 2.99 & 0.35 & 9.91 & 6.36 \\
\hline 12 & Big & Oct-16 & Apr-17 & May-18 & Jul-19 & 2.88 & 0.47 & 7.85 & 10.07 \\
\hline 13 & Big & Oct-16 & Apr-17 & May-18 & Jul-19 & 4.25 & 0.51 & 2.22 & 4.44 \\
\hline 14 & Big & Oct-16 & Apr-17 & May-18 & Jul-19 & 1.89 & 0.52 & 4.82 & 10.02 \\
\hline 15 & Little & Oct-16 & Apr-17 & May-18 & Jul-19 & 4.68 & 0.24 & 6.84 & 11.04 \\
\hline 16 & Little & Oct-16 & Apr-17 & May-18 & Jul-19 & 3.37 & 0.19 & 4.30 & 14.55 \\
\hline 17 & Little & Oct-16 & Apr-17 & May-18 & Jul-19 & 2.04 & 0.46 & 3.37 & 6.22 \\
\hline 18 & Little & Oct-16 & Apr-17 & May-18 & Jul-19 & 2.45 & 0.10 & 4.90 & 12.48 \\
\hline 19 & Little & Oct-16 & Apr-17 & May-18 & Jul-19 & 2.23 & 0.55 & 3.78 & 7.14 \\
\hline 20 & Little & Oct-16 & Apr-17 & May-18 & Jul-19 & 2.01 & 0.61 & 4.76 & 10.85 \\
\hline 21 & Little & Oct-16 & Apr-17 & May-18 & Jul-19 & 4.25 & 0.42 & 3.17 & 7.05 \\
\hline 22 & Little & Oct-16 & Apr-17 & May-18 & Jul-19 & 2.59 & 0.35 & 4.37 & 17.94 \\
\hline 23 & Little & Oct-16 & Apr-17 & May-18 & Jul-19 & 1.76 & 0.62 & 4.12 & 18.28 \\
\hline 24 & Big & Oct-16 & Apr-17 & May-18 & Jul-19 & 2.94 & 0.40 & 4.18 & 7.14 \\
\hline 25 & Big & Oct-16 & Apr-17 & May-18 & Jul-19 & 2.04 & 0.65 & 4.74 & 10.85 \\
\hline 26 & Big & Oct-16 & Apr-17 & May-18 & Jul-19 & 2.45 & 0.21 & 3.29 & 7.05 \\
\hline 27 & Big & Oct-16 & Apr-17 & May-18 & Jul-19 & 2.67 & 0.42 & 3.95 & 17.94 \\
\hline 28 & Big & Oct-16 & Apr-17 & May-18 & Jul-19 & 1.37 & 0.67 & 3.15 & 18.28 \\
\hline 29 & Big & Oct-16 & Apr-17 & May-18 & Jul-19 & 1.32 & 0.52 & 3.95 & 18.10 \\
\hline
\end{tabular}

most of the study area. The average particle size distribution was approximately 77 percent sand, 16 percent silt, and 7 percent clay. Clay-size particles require a flow no greater than $7 \mathrm{~m}^{3} / \mathrm{sec}$ for deposition; because of their size and structure, these particles will only be deposited in low energy waters (Phillips \& Slattery, 2007). Environmental flows in Big Cypress Bayou are partially controlled by water release upstream at Lake O' the Pines and tributary contributions, with a mean 
annual discharge of $8.5 \mathrm{~m}^{3} / \mathrm{sec}$ as recorded by the USGS gaging station located near Jefferson, Texas (USGS, 2020). Locations 14 and 23 are located close to the confluence of Little Cypress Bayou and Big Cypress Bayou; however, Little Cypress Bayou does not always flow into Big Cypress Bayou except during higher water periods.

Sample location six is near the front of a retention pond that only receives and loses water when there are higher floodwaters. Overall, the samples exhibit a fairly uniform texture, primarily controlled by the flow regime in Big Cypress Bayou.

\section{Discussion}

Most metals occur naturally in geologic materials and are represented in the sediments and rocks in the Earth's crust. Base metals are those that are typically scarce, nonprecious, non-ferric (do not occur in the +3 valence state) metals of copper, lead, zinc, tin, mercury, and cadmium. During the study period, all concentrations of tin and cadmium were below the detection limit and not reported. Although several sampling locations reported elevated mercury levels, all other metals were within normal limits and well below the impairment threshold of the EPA and TCEQ.

The spike in concentrations near major highways and industrial complexes suggests some of these metals may have been introduced by anthropogenic means as runoff from road ways, rather than naturally occurring as trace concentrations in geologic sediments (MDOT, 1998; Müller et al., 2019). The geologic formations from the Wilcox and Claiborne groups are silicate-based claystones, siltstones, and sandstones with no appreciable metal concentrations associated with $\mathrm{Cu}, \mathrm{Hg}, \mathrm{Pb}$, and $\mathrm{Zn}$ reported in the literature (Fisher, 1964; Eargle, 1968; Galloway et al., 2000).

\subsection{Copper}

Copper is a moderately abundant base metal that occurs as a free native element or in association with copper minerals in igneous, sedimentary, and metamorphic rocks. Copper has an abundance of approximately 14 to $32 \mathrm{ppm}$ in the Earth's upper crust (Walther, 2014) and is also present in the oceans and fresh waterbodies, and widely distributed in the natural environment by wind-blown dust, decaying vegetation, forest fires, volcanic eruptions, and sea spray. It is a necessary element for plant growth, and helps support metabolic functions of aquatic organisms (EPA, 2016a).

As a contaminant, copper can also be disbursed by anthropogenic means such as mining, metal production, combustion of fossil fuels, industrial use in manufacturing, and agriculture. It has been used in brake pads for automobiles and can be introduced into the natural environment as runoff from parking lots and roadways (MDOT, 1998; Müller et al., 2019). Most copper compounds released to the atmosphere will settle and be bound to either water, sediment, or soil particles (Walther, 2014). Some of the water samples reported copper concentra- 
tions above the $10 \mathrm{ppb}$ for EPA National Primary Drinking Water Regulations (EPA, 2020a), but all samples were well below the actionable standard of 1300 ppb.

\subsection{Mercury}

Mercury is rare in the Earth's crust, with an estimated average abundance of 0.01 to $0.06 \mathrm{ppm}$ (Walther, 2014). It is one of the most toxic and volatile trace elements, and undergoes a series of complex chemical reactions and physical transformations in the environment (Anderson, 2013). Much of the Hg found in lake and stream sediments in the East Texas area is attributed to atmospheric deposition associated with the combustion of fossil fuels (Tewalt et al., 2001). In February 1998, the US Environmental Protection Agency issued a report citing mercury emissions from electric utilities as the largest remaining anthropogenic source of Hg released to the atmosphere (US Geological Survey, 2000). Mercury is easily transported to the atmosphere by volatilization, and because of an imbalance with uptake by the ocean's surface, can remain in the atmosphere for up to one year (US Geological Survey, 2000). In its metallic form, mercury is essentially inert, and can persist for an extended period of time sequestered in sediments and soils.

The global cycle of mercury is largely controlled by oxidation-reduction reactions in the atmosphere and in surface waters that readily convert volatile $\mathrm{Hg}(0)$ into soluble $\mathrm{Hg}^{2+}$ and vice versa (USGS, 1995; TCEQ, 2004). A small fraction of mercury in natural waters is converted by bacteria in anoxic environments; certain anaerobic microorganisms can mediate the methylation of mercury to methylmercury $\left[\mathrm{CH}_{3} \mathrm{Hg}\right]^{+}$or dimethylmercury $\left(\mathrm{CH}_{3} \mathrm{HgCH}_{3}\right)$. These highly soluble species are readily taken up by aquatic organisms, particularly fish and shellfish (USGS, 1995). Once Hg has entered the food chain, it can reach concentrations of several thousand parts per million in organisms at the highest trophic levels (Deonarine, 2011). At these concentrations levels, $\mathrm{Hg}$ is hazardous to human health. In Caddo Lake, the low dissolved oxygen impairment in the western arm provides a prime environment for reduced conditions that promote uptake of soluble $\mathrm{Hg}$ species by fish and shellfish, leading to an edible tissue advisory. In the Caddo Lake watershed, flowing, oxygenated waters and stable $\mathrm{pH}$ values do not facilitate the methylation process. In areas where the water is more stagnant during low flow periods, anoxic conditions can develop and promote the methylation process (Demer, 2009). During the study period, only one water sample contained elevated mercury, with all others below the EPA threshold of 2 ppb. Several sediment samples contained elevated mercury concentrations, but the field data supports a well-oxygenated stream system that does not favor methylation (Watkins, 2018; Faulkner \& Stafford, 2019; Ertons \& Faulkner, 2020). Mercury has been reported bound to pyrite in the lignite coal seams associated with the Wilcox Group (Paul et al., 2008), but no active mining or outcrop exposures in the study area would lead to the conclusion that mercury was introduced into the watershed by hydrogeologic or erosional processes. 
In 2016, research was conducted by Zhang et al. (2016) at Harvard University regarding the global decrease in atmospheric $\mathrm{Hg}$ by anthropogenic emissions. This study reported a measured decline in North America and Europe of approximately one to two percent per year from 1990 to 2015. They identified a 20 to 30 percent decrease in global $\mathrm{Hg}$ emissions but a much larger decrease in North America and Europe that offsets the effects of increasing emissions from Asia. The findings of the study have reinforced the major benefits derived from the phase-out of $\mathrm{Hg}$ in several products and emission controls on coal combustion (Zhang et al., 2016). This study also concluded that the Hg deposited locally around coal-fired power plants has declined more rapidly than originally anticipated, resulting from reduced sulfur dioxide and nitrous oxide emissions from coal-fired utilities (Zhang et al., 2016). Even though Hg metal concentrations are diminishing in the watershed, the conditions still exist in Caddo Lake for $\mathrm{Hg}$ methylation and uptake by aquatic organisms because $\mathrm{Hg}$ is so persistent in the environment and some atmospheric deposition will continue associated with global sources.

\subsection{Lead}

Native lead is rare in nature, it is usually found in ore rock associated with zinc, silver, and copper, with an average abundance of 17 to $18 \mathrm{ppm}$ in the Earth's upper crust (Walther, 2014). Lead can be found in all parts of our environment including air, soil, and water, and is widely dispersed in igneous and sedimentary rocks such as shales and carbonates. It became the dominant base metal in the early 1900s and because of the combination of lead's desirable properties-dense, soft, easily worked, and corrosion resistant-it was used in weights, solders, ceramic glazes, paints, and lead crystal glassware (Walther, 2014).

Although lead occurs naturally in the environment, most significant lead concentrations of concern are the result of human activity. Human exposure can be the result of contact with leaded gasoline, industrial facilities, and lead-based paint (EPA, 2019c). One if its major uses is in the glass of computer and television screens, where it shields the viewer from radiation; other uses are in sheeting, cables, ammunitions, bearings, and as weight in sport equipment. In the United States, approximately $87 \%$ of lead has been used for the production of lead-acid batteries for automobiles (Walther, 2014). When lead is released to the air from industrial sources or spark-ignition engine aircraft, it may travel long distances before settling to the ground, where it usually binds to soil particles. Lead may move from soil into ground water depending on the type of lead compound and the characteristics of the soil (EPA, 2015). All lead concentrations were below the actionable standards for both water (15 ppb) and sediment (200 ppb) samples (EPA, 2020a).

\subsection{Zinc}

Zinc is the most common base metal that occurs naturally in metallic ore deposits, air, water, and soil, with an average abundance in the Earth's upper conti- 
nental crust between 52 and 70 ppm (Walther, 2014). Zinc concentrations are rising due to anthropogenic activities; most zinc is added during industrial activities such as mining, coal and waste combustion, and steel processing. Some soils are heavily contaminated with zinc, and are found in areas where zinc has been mined or refined, or where sewage sludge from industrial areas has been used as fertilizer (EPA, 2015).

With regard to both water and sediment samples in the Caddo Lake watershed, zinc was enriched in comparison to copper and lead. Zinc concentrations may be associated with anthropogenic sources; $\mathrm{Zn}$ is used to galvanize steel to prevent rust, an alloy in metal machine parts, alloyed with copper to make brass, roofing materials, paint pigments, and personal use items. Industry use of $\mathrm{Zn}$ in manufacturing, paint, and other industries may be providing a point source for atmospheric deposition of Zn (Müller et al., 2019), particularly in Black Cypress and Big Cypress bayous. Industrial facilities near the city of Jefferson and transportation facilities may be contributing to elevated zinc concentrations, although at present, there are no EPA or TCEQ actionable standards for zinc concentrations in water or sediments.

\section{Conclusion}

This multi-year study was conducted to provide baseline geochemical data for Black Cypress, Big Cypress, and Little Cypress bayous to determine their contribution to the metal concentrations in the Caddo Lake watershed and western Caddo Lake. During this study period, the use of lignite coal was waning in East Texas. Because of the shift in price and continued efforts to meet emission standards, many electrical power stations had switched from coal to natural gas as their primary energy source. A reduction in the use of lignite would have reduced emissions in the immediate area, although global sources would still have an impact on the accumulation of metals in the Caddo Lake.

The nature of the sediment particles may have also played a role in the lower metal concentrations; metals are more readily sequestered by clay-sized particles, and the sand-dominant sediment samples may not retain significant concentrations of the metals of interest. Caddo Lake continues to be impaired for mercury in edible tissue and low dissolved oxygen, but these data show that Big Cypress, Black Cypress, and Little Cypress bayous are not significantly contributing to the impairment of the water body. More likely, atmospheric deposition from local and global sources has contributed to the mercury concentrations reported in the sediments in the Caddo Lake watershed.

\section{Acknowledgements}

Partial funding for this project was provided by the SFA Office of Research and Sponsored Program's Student-Faculty Collaborative Research Grant and the Summer Undergraduate Research Experience sponsored by the College of Sciences and Mathematics at Stephen F. Austin State University. Transportation and wa- 
tercraft for stream sampling were provided by the Division of Environmental Science, Arthur Temple College of Forestry and Agriculture. Courtney Booker, Will Gray, Roquell Pettigrew, and Ashley Schutt provided valuable field assistance when collecting water and sediment samples in Little Cypress Bayou.

\section{Conflicts of Interest}

The authors declare no conflicts of interest regarding the publication of this paper.

\section{References}

Albertson, P. E., \& Dunbar, J. B. (1993). Geomorphic Investigation of Shreveport to Daingerfield Navigation Project. U.S. Army Corps of Engineers, Vicksburg District, Geotechnical Laboratory (U.S.) Engineer Research and Development Center, Report TR GL-93-31. https://apps.dtic.mil/dtic/tr/fulltext/u2/a275242.pdf

Anderson, J. J. (2013). Mobilization of Hg-Contaminated Sediment in a Regulated River, Androscoggin River, Northern New Hampshire. M.Sc. Thesis, Hanover: Dartmouth College.

Aquatic Life Ambient Water Quality Criteria, EPA 822-F-16-004. Washington DC: Office of Water Resources.

https://archive.epa.gov/epa/sites/production/files/2016-08/documents/copper-estuarin e-marine-draft-factsheet.pdf

Ashworth, J., Keyes, D., Kirk, R., \& Lessard, R. (2001). Standard Procedure in the Hydrometer Method for Particle Size Analysis. Communications in Soil Science and Plant Analysis, 32, 633-642. https://doi.org/10.1081/CSS-100103897

Crowe, A., \& Hambleton, F. (1998). Cypress Creek Basin Aquatic Life Use and Dissolved Oxygen Concentrations during Low-Flow, High Stress Summer Conditions 1995-1996. Report AS-157-SR. Texas Natural Resources Conservation Commission: Austin, Texas. http://caddolakedata.us/media/1944/texas\%20natural\%20resource\%20conservation\%2 0commission\%201998.pdf

Demer, J. D. (2009). Mercury at the Terrestrial-Aquatic Interface: The Biogeochemical Cycling of Mercury in Wetlands of Different Hydrogeologic Setting, and during Snowmelt in a Forested Headwater Stream. PhD Thesis, Ithaca, NY: Cornell University.

Deonarine, A. (2011). Sources of Biogeochemical Transformation of Mercury in Aquatic Ecosystems. PhD Thesis, Durham: Department of Civil Environmental Engineering, Duke University.

Eargle, D. H. (1968). Nomenclature of Formations of Claiborne Group Middle Eocene, Coastal Plain of Texas. Geological Survey Bulletin 1251-D, Washington DC: United States Geological Survey. https://pubs.usgs.gov/bul/1251d/report.pdf

Environmental Protection Agency (2015). National Emissions Inventory, Version 2, Technical Support Document (p. 32). Washington DC.

https://www.epa.gov/sites/production/files/2015-10/documents/nei2011v2_tsd_14aug2 015.pdf

Environmental Protection Agency (2016a). Fact Sheet: Draft Estuarine/Marine Copper.

Environmental Protection Agency (2016b). EPA Method 6010C (SW-846): Inductively Coupled Plasma-Atomic Emission Spectrometry. Washington DC: Office of Hazardous Waste Test Methods.

https://19january2017snapshot.epa.gov/homeland-security-research/epa-method-6010 
c-sw-846-inductively-coupled-plasma-atomic-emission_.html

Environmental Protection Agency (2019a). EPA Method 3050B: Acid Digestion of Sediments, Sludges, and Soils. Washington DC: Office of Hazardous Waste Test Methods. https://www.epa.gov/esam/epa-method-3050b-acid-digestion-sediments-sludges-and-s oils

Environmental Protection Agency (2019b). EPA Method 7471B (SW-846): Mercury in Solid or Semisolid Wastes (Manual Cold-Vapor Technique). Washington DC: Office of Hazardous Waste Test Methods.

https://www.epa.gov/esam/epa-method-7471b-sw-846-mercury-solid-or-semisolid-was tes-manual-cold-vapor-technique

Environmental Protection Agency (2019c). Learn about Lead: Basic Information about Lead. Washington DC: Office of Environmental Education.

https://www.epa.gov/lead/learn-about-lead

Environmental Protection Agency (2020a). National Primary Drinking Water Regulations. Washington DC: Office of Ground Water and Drinking Water Standards. https://www.epa.gov/ground-water-and-drinking-water/national-primary-drinking-wa ter-regulations

Environmental Protection Agency (2020b). Regional Screening Levels (RSLs) for Resident Soil. Washington DC: Office of Risk Management.

https://www.epa.gov/risk/regional-screening-levels-rsls-generic-tables

Ertons, M. L., \& Faulkner, M. S. (2020). Geochemical Analyses of Base Metals in Sediments and Stream Water, Black Cypress Bayou, Marion County, Texas. Undergraduate Research Conference, Nacogdoches, TX: Stephen F. Austin State University.

https://scholarworks.sfasu.edu/urc/2020/Posters/14

Faulkner, M. S., \& Stafford, K. W. (2019). Heavy Metal Concentrations in Big Cypress and Black Cypress Bayous, Caddo Lake Watershed, Texas. In Abstracts with Programs (Vol. 51, No. 2, p. 24). Manhattan, KS.

https://doi.org/10.1130/abs/2019SC-327263

Fisher, W. L. (1964). Sedimentary Patterns in Eocene Cyclic Deposits, Northern Gulf Coast Region. In Symposium on Cyclic Sedimentation: Kansas Geological Survey, Bulletin 169 (pp. 151-170). Austin, TX: Bureau of Economic Geology.

http://www.kgs.ku.edu/Publications/Bulletins/169/Fisher

Galloway, W. E., Ganey-Curry, P. E., Li, X., \& Buffler, R. (2000). Cenozoic Depositional History of the Gulf of Mexico Basin. American Association of Petroleum Geologists Bulletin, 84, 1743-1774.

https://doi.org/10.1306/8626C37F-173B-11D7-8645000102C1865D

Hartung, A. A. (1983). Physicochemical Limnology of Caddo Lake, Texas and Louisiana. MS Thesis, Nacogdoches, TX: Stephen F Austin State University.

Lisantti, J. (2001). Measuring Modern Sedimentation Rates in Caddo Lake (LA, TX) Using 137cs Depth Profile. Gulf Coast Association of Geological Societies Transactions, L1, 459-461.

MDOT Michigan Department of Transportation (1998). Highway Stormwater Runoff Study.

https://www.michigan.gov/documents/MDOT_MS4_MDOT_Hwy_SW_Runoff_Study 91946_7.pdf

Müller, A., Österlund, H., Marsalke, J., \& Viklander, M. (2019). The Pollution Conveyed by Urban Runoff: A Review of Sources. Science of the Total Environment, 709, Article ID: 136125. https://doi.org/10.1016/j.scitotenv.2019.136125

Paul, J. C., Steinbach, P. B., \& Ownby, D. R. (2008). Distribution of Mercury in a Gulf 
Coast Lignite Mine. Energy \& Fuels, 22, 3949-3954. https://doi.org/10.1021/ef800291b

Phillips, J. D., \& Slattery, M. C. (2007). Geomorphic Processes, Controls, and Transition Zones in the Lower Sabine River. Report for the Texas Water Development Board, Louisville, KY: University of Kentucky.

http://www.twdb.texas.gov/publications/reports/contracted_reports/doc/0600010595_S abine.pdf

Shaw, M. G. (2006). Geologic Control of Stream Water Composition in Cherokee, Smith, and Rusk Counties, Texas. MS Thesis, Nacogdoches, TX: Stephen F Austin State University.

TCEQ Texas Commission on Environmental Quality (2004). Strategy for Addressing Mercury Contamination in Fish Tissue in Caddo Lake. Austin, TX: Texas Commission on Environmental Quality. http://caddolakedata.us/media/266/tceq2004.pdf

TCEQ Texas Commission on Environmental Quality (2020). The 2020 Texas Integrated Report of Surface Water Quality, 2020 Texas 303(d) List. Austin, TX: Texas Commission on Environmental Quality.

https://www.tceq.texas.gov/assets/public/waterquality/swqm/assess/20txir/2020_303d.p df

Tewalt, S. J., Bragg, L. J., \& Finkelman, R. B. (2001). Mercury in U.S. Coal-Abundance, Distribution, and Modes of Occurrence. U.S. Geological Survey FS-095-01, Washington DC: U.S. Department of the Interior.

TNRIS Texas Natural Resource Information System (2020). Texas Water Development Board Surface Water Database. https://tnris.org

Twidwell, S. (2000). Bioaccumulation of Mercury in Selected East Texas Water Bodies. AS-180, Austin, TX: Texas Natural Resources Conservation Commission.

U.S. Geological Survey (2000). Mercury in the Environment. Fact Sheet 146-00, U.S. Geological Survey, U.S. Department of the Interior. https://www2.usgs.gov/themes/factsheet/146-00

USFW United States Fish \& Wildlife Service (2012). History of the Longhorn Army Ammunition Plant. Washington DC: U.S. Department of the Interior. https://www.fws.gov/refuge/Caddo_Lake/about/amm_plant.html

USGS United States Geological Survey (1995). Mercury Contamination of Aquatic Ecosystems. Fact Sheet FS-216-95, U.S. Geological Survey, U.S. Department of the Interior. https://pubs.usgs.gov/fs/1995/fs216-95/pdf/fs21695.pdf

USGS United States Geological Survey (2020). Depth and Discharge Data from the Gaging Station Located on Big Cypress Bayou at Jefferson, Texas. https://waterdata.usgs.gov/nwis/uv?site_no $=07346000$

Walther, J. V. (2014). Ch. 8: Scarce Metals: Base Metals. In Earth's Natural Resources (pp. 177-202). Burlington, MA: Jones \& Bartlett Learning.

Watkins, J. D. (2018). Mercury in Big Cypress Bayou and Caddo Lake Watersheds in Marion and Harrison Counties, Texas. MS Thesis, Nacogdoches, TX: Stephen F. Austin State University.

Wilson, J. T. (2003). Occurrences of and Trends in Selected Sediment-Associated Contaminants in Caddo Lake, East Texas, 1940-2002. Water-Resources Investigations Report 03-4253, Austin, TX: U.S. Geological Survey. http://caddolakedata.us/media/530/wilson-caddo-sediments.pdf

Winemiller, K. O., Chin, A., Davis, S. E., Roelke, D. L., Romero, L. M., \& Wilcox, B. P. (2005). Summary Report Supporting the Development of Flow Recommendations for the Stretch of Big Cypress Creek below Lake O' the Pines Dam. College Station, TX: 
Texas A\&M University.

http://caddolakedata.us/media/1494/tamu_summaryreport_april2005.pdf

Zhang, Y., Jacob, D. J., Horowitz, H. M., Chen, L., Amos, H. M., Krabbenhoft, D. P., Slemr, F., St. Louis, V. L., \& Sunderland, E. M. (2016). Observed Decrease in Atmospheric Mercury Explained by Global Decline in Anthropogenic Emissions. PNAS, 113, 526-531. https://doi.org/10.1073/pnas.1516312113 